\title{
Domestic Violence, Alcohol Consumption and Depression in Criminal Population
}

\author{
Patricia Martínez Lanz, María José Fernández Díaz \\ Universidad Anáhuac, México City, México \\ Email:pmlanz@anahuac.mx
}

Received November 21 ${ }^{\text {st }}, 2012$; revised January $2^{\text {nd }}$, 2013; accepted February $5^{\text {th }}, 2013$

\begin{abstract}
The objective of this research was to determine the differences in levels of domestic violence, alcohol and depression by type of crime committed on 259 men and 200 women inmates of the Centre for Social Rehabilitation in Mexico. To assess alcohol consumption indicators were adapted from the National Addiction Survey, the CES-D was used to measure depressive symptoms and in terms of domestic violence, we designed a 16-reactive scale evaluating: verbal aggression, physical aggression, humiliation and respect. The results showed significant differences not by gender but by type of crime committed, specifically on domestic violence, in which was found that women had higher scores than men. Furthermore, the analysis by type of crime committed found a higher number of subjects with severe consumption that health damages and homicides. Regarding depressive symptoms, the results showed that women had higher scores than men; however, these differences were not significant. In conclusion, data indicate relevant differences by gender in terms of domestic violence, depressive symptoms and substance use, but not so, on the type of crime by substance consumption, depression or family violence.
\end{abstract}

Keywords: Violence; Alcohol Consumption; Depression; Criminal Population; Gender

\section{Introduction}

According to the results of the Sixth National Survey on Insecurity (Citizens' Institute for Studies on Insecurity, 2009) on the rate of criminal behavior in Mexico, during 2008, the number of complaints received showed an increase of $5.7 \%$ over the previous year, from 1622, 304 complaints in 2007 to 1, 714.771 in 2008. However, it is important to note that some studies estimate that of the total crimes commited, only $22 \%$ are reported to the authority and of those, only $15 \%$ of cases initiated a preliminary research.

Due to the increase in criminal behavior, the need to develop prevention and intervention programs to reduce this problem, hence, it is important to determine which factors are associated with the presence of such behavior. According to the literature, there are multiple causes related to criminal behavior, however, there have been found some factors that affect more importantly, for example, low socioeconomic levels, educational deficiencies , poverty, inadequate family environments, living in risky neighborhoods and belong to large families (Hernández \& Marquez, 2000; Romero, 2003; Romero \& Aguilera, 2002).

On the other hand, some studies have found different risks for the development of behavior between men and women (Fagan, Van Horn, Hawkins, \& Arthur, 2007; Gorman-Smith \& Loeber, 2005; Hart, O’Toole, Price-Sharps, \& Shaffer, 2007). For example, in a study by Fagan et al. (2007) it was found that men, who had a greater number of peers with criminal behavior, were more rebellious and had academic failure and were more likely to commit criminal behavior. As regards women, this study reported that high scores on family conflict and low levels of attachment to parents were the risk factors to become involved in criminal behavior.

According to Heise, Pitanguy and Germain (1994), violence is an important factor in the risk to present criminal behavior, particularly that which occurs within the family environment that may include elements such as rape, physical or psychological abuse and sexual abuse. Rodríguez, Romero, Durand, Colmenares and Saldivar (2006) indicated that women who go into crime report having experienced violence from their parents or those who witnessed the mistreatment of his mother got, so habituated to this type of behavior that became permissive.

Others (Cicchetti, 2004; Ireland, Smith, \& Thornberry, 2002; Martínez-Lanz, Betancourt, Rendón, \& Burns, 2012; MartínezLanz, Lobo, \& Vecchi, 2012; Pérez \& Pinzon, 2009; Sabol, Coulton, \& Korbin, 2004; Thornberry, Ireland, \& Smith, 2001), suggest that physical abuse and exposure to domestic violence during childhood are considered important factors for the presence of behavioral problems in young people, among which are the criminal conduct.

In Mexico, Frías, Sotomayor, Varela, Zaragoza, Banda and Garcia (2000) conducted a study with young offenders, the authors found a positive relationship between parental physical abuse and antisocial behavior, criminal behavior of young people was predicted from antisocial behavior and physical abuse from the father. The authors conclude that the violent behavior of parents is a contributing factor to antisocial behavior which in turn is a prelude to commit criminal acts.

On the other hand, there is evidence that the use and abuse of substances is a risk factor for aggressive behavior and submit to commit criminal acts in people with certain psychiatric disorders such as schizophrenia (Strawberries, Tejero, Apiquian, Loyzaga, García-Anaya, \& Nicolini, 2002). Other authors (Norstrom, 1998; von Hofer, 2003) have reported that alcohol consumption is strongly associated with criminal behavior such as homicides and assaults, and that a considerable proportion of 
violent crimes are committed by individuals who have consumed alcohol or drugs (Grann \& Fazel, 2004; Pérez \& Pinzon, 2009).

Another aspect that has been linked to criminal behavior are mental disorders, for example, Huizinga and Jakob-Chien (1998) and Vicens, Tort, Dueñas, Muro, Pérez-Arnau, Arroyo et al., (2012) found that youth who have committed some type of criminal behavior have high levels of mental disorders compared to youth who do not have done this type of behavior. In a review by Fazel and Danesh (2002) showed that mental disorders may be more common in prison population compared with the normal population, however, the findings vary considerably between studies, where some reported prevalence of $37 \%$ and other of up to $94 \%$.

Among mental disorders, one that often occurs is depression. Some studies report significant relationships between depressive symptoms and the presence of antisocial behavior (Chiles, Cleve, Jemelka, \& Trupin, 1980; Pliszka, Sherman, Barrow, \& Irick, 2000; Vermeiren, Deboutte, Ruchkin, \& Schwab-Stone, 2002). Nebbitt and Lombe (2008) found that youth who reported a greater number of behaviors were those who reported having favorable attitudes toward deviant behavior, having a high exposure to peers with delinquent behavior and having depressive symptoms.

Recent research indicates that the level of mental health in adolescents moderates the influence of individual and social factors on antisocial behavior (Nebbitt \& Lombre, 2008, Novak, Burgess, \& Clark, 2003; Stewart, Karp, Phil, \& Peterson, 1997). It is suggested that psychological functioning (for example, depression) serve as moderating variables between exposure to environmental stressors and behavior risk to health (Sanders-Phillips, 2001).

Although depression is associated with the carrying out of antisocial and criminal behavior, there is also evidence to suggest that once the person was detained for committing criminal behavior may suffer from depressive disorders due to the social, economic and family the penalty involved (Martínez-Lanz, Betancourt, Rendón, \& Burns, 2012; Romero \& Aguilar, 2002). For example, Galván, Romero, Rodríguez, Durand, Colmenares \& Saldivar (2006) reported a relationship between the frequency of visits in prison with the presence or absence of depression, specifically in women, i.e., women who did not receive visitors in about a month or longer have an increased number of depressive episodes. Another factor that the authors report is the forced separation of the women and their children.

Based on the literature review, the hypothesis being tested in this research is whether the inmates of a prison in Mexico who committed more violent crimes, have higher scores of domestic violence, depressive symptoms and increased substance use (prior the admission to prison), than those who committed crimes with less violence. Hence, the objective was to determine the differences in levels of domestic violence, alcohol consumption and depression on the type of crime committed between men and women inmates of Social Rehabilitation Centre (CERESO) the state of Morelos, Mexico.

\section{Method}

\section{Participants}

A total of 459 participants were involved, of whom 200 were women (total female population in detention) and 259 men (sample of detained male population) who were inmates of Social Rehabilitation Centre (CERESO) of the State of Morelos, Mexico. The average age of women was 36.7 years and men 42.5 years. Both men and women the highest percentage mentioned living together (40\% for women and $39.1 \%$ for men). Regarding the school level, a greater number of women reported having incomplete primary (30.2\%), followed by complete primary (27.5\%) and thirdly, complete secondary (19.5\%). Referring to men, the highest percentage referred to the complete secondary (26.3\%), second, completed primary (23.9\%), and followed by incomplete primary (23.1\%).

\section{Measures}

To assess alcohol consumption four indicators used in the National Survey of Addictions 1993 were adjusted (Tapia, Cravioto, De la Rosa, Kuri, \& Gomez, 1995). They measured the amount and type of alcoholic beverage consumed (prior sentence), with 4 response options for each four indicators: from not consume at all to consume more than five drinks on a single occasion.

To measure current depressive symptomatology Schedule of Center for Epidemiologic Studies was used (CES-D) (Radloff, 1977; Mariño Medina-Mora, Chaparro, \& González-Forteza, 1993), which consists of 20 items to measure the presence and duration of depressive symptoms during the week prior to implementation. We adapted the scale Child Abuse Scale (Vladimirsky, Sanchez, \& Marin, 2003) to measure family violence (prior to entering the CERESO); the final scale was composed for 16 items that measure: verbal aggression, physical aggression, humiliation and respect.

To verify that the information obtained would be valid and reliable, pilot tests on the instruments were carried out, for both men and women. Results of the validity of the scale of Domestic Violence, showed that the items were regrouped into the four dimensions of the original scale (verbal aggression, physical aggression, humiliation and respect) and showed adequate reliability ( $\alpha=.83$ ). For the CES-D, exploratory factor analysis showed three factors: negative affect, positive affect and feelings of failure and attention, the reliability of the instrument was acceptable $(\alpha=.74)$.

\section{Procedure}

The authorities of the Social Rehabilitation Center of Morelos, Mexico, solicited a study on depression of the inmates and the authors insisted on study other variables such as substance consumption and family violence.

The CERESO authorities assigned personnel to assist in the application of the instruments and they were capacitated. This staff explained to the inmates the purpose of the research, the contents of the instrument, the confidentiality of the information and asked for their voluntary participation and their consent to answer the instrument in order to have a better understanding of this variables. Doubts were clarified.

After training, the staff of the institution made the application of this instrument in one session for each gender. When instruments were done, participants placed them in sealed envelopes in a box before leaving the space where they are applied.

Data analysis was conducted with SPSS version 20: descriptive analysis to examine the distribution of participants in each of these variables and inferential analysis for hypothesis testing. 


\section{Results}

As regards to the type of offense and gender of participants, we found a statistically significant relation $\left(X^{2}=41.49, p\right.$ $<$.001). As shown in Figure 1, a greater number of participants, both men and women, were detained for committing health damages. In the case of women, in second place was detected those who were in prison for kidnapping, for men was murder. Thirdly, for women were those who committed robbery and rape for men.

Levels of domestic violence, alcohol and depression by gender, significant relationships were found for the three variables (see Table 1). The results showed that men were more common to have low levels of violence, alcohol consumption and depression. In the case of women, they had high levels in both violence and alcohol consumption and depression.

Figure 2 shows the results on the relationship between levels of violence by type of crime committed. The findings showed a significant relationship $\left(X^{2}=33.52, p<.001\right)$ between levels of violence and type of crime committed, as you can see, the crime where a larger number of participants had severe levels of violence was damage to health $(41 \%)$, followed by those who committed homicide $(23.1 \%)$ and third place were those who committed robbery (15.4\%).

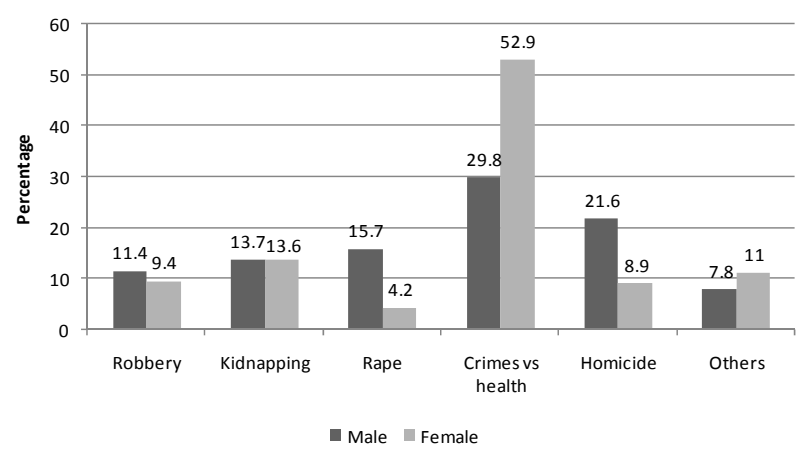

Figure 1.

Type of crime committed by gender.

Table 1.

Levels of violence, alcohol and depression by gender.

\begin{tabular}{ccccc}
\hline & & Male & Female & \multirow{2}{*}{$\boldsymbol{X}^{2}$} \\
\cline { 2 - 4 } & Level & $\%$ & $\%$ & \\
\hline \multirow{2}{*}{ Violence } & Low & 86.0 & - & \\
& High & 11.7 & 77.8 & \multirow{2}{*}{$269.06^{* * *}$} \\
& Severe & 2.3 & 22.2 & \\
Alcohol & Low & 51.2 & 47.2 & \\
consumption & High & 30.2 & 52.8 & \multirow{2}{*}{$34.37^{* * *}$} \\
& Severe & 18.6 & - & \\
& Low & 54.3 & 32.9 & \\
Depression & High & 41.3 & 51.4 & \multirow{2}{*}{$23.33^{* * *}$} \\
& Severe & 4.5 & 15.8 & \\
\hline
\end{tabular}

Note: ${ }^{* * *} p<.001$.
In terms of alcohol consumption levels for the crime committed, the results indicated that there is no significant relationship between these variables $\left(X^{2}=6.43, p>.05\right)$. As can be seen in Figure 3, 41\% of subjects who had a severe level of consumption were those who committed health damages, followed by those who committed homicide (20.5\%).

With respect to levels of depression for the crime committed, the results showed no significant relationship $\left(X^{2}=7.47, p\right.$ $>$.05). In Figure 4, we can see that, as in the previous analysis, the highest percentage (42.4\%) participants who had severe levels of depression were those who are detained for committing health damages, second were those who committed murder and other crimes (15.2\%, respectively).

To determine the differences between family violence, alcohol and depression among men and women by type of crime, we used an analysis of variance (see Table 2) that showed significant effects by sex $(F=12.43, p<.001)$, but not by crime $(F=1.05, p>.05)$. In regards to the interaction of sex by type of crime, the results were significant only for family violence, where women had higher scores in violence in most crimes except in health damages compared to men.

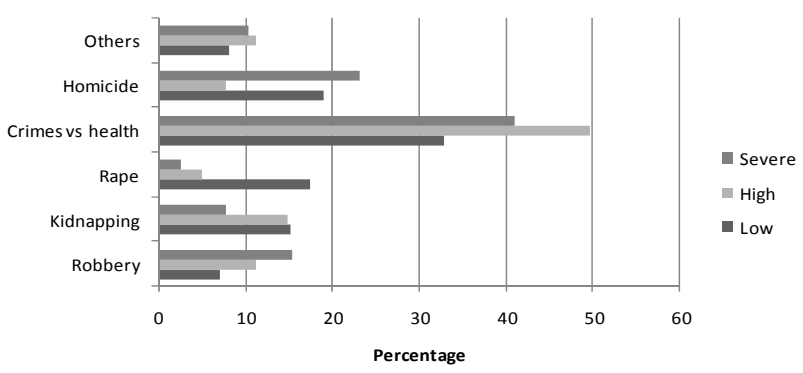

Figure 2.

Levels of violence by type of crime.

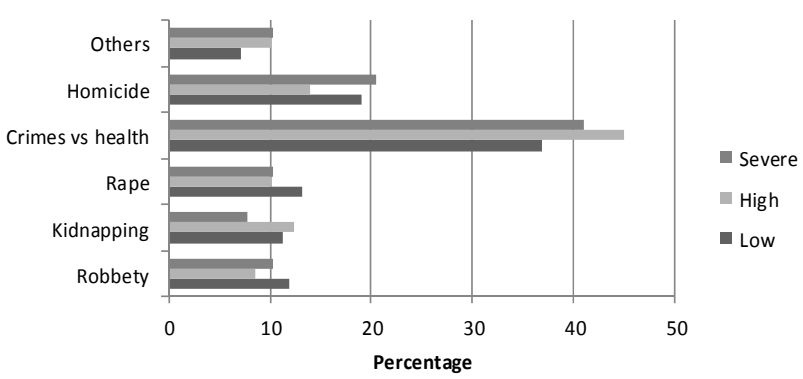

Figure 3.

Levels of alcohol consumption by type of crime.

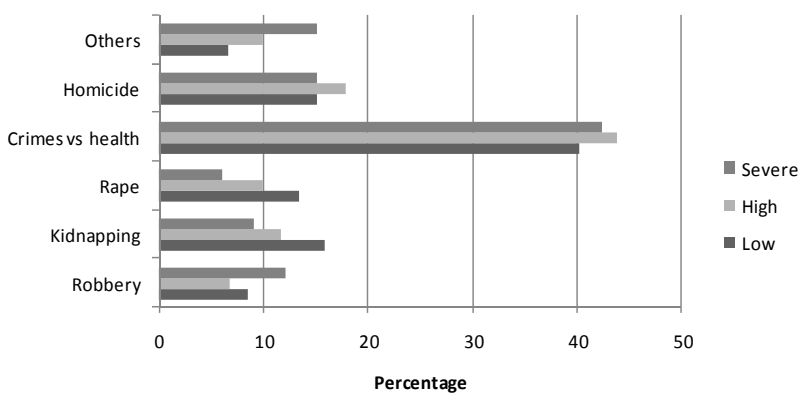

Figure 4.

Depression levels by type of crime. 
Table 2.

Violence, alcohol and depression by gender and crime.

\begin{tabular}{|c|c|c|c|c|c|c|c|}
\hline & & \multicolumn{2}{|c|}{ Violence } & \multicolumn{2}{|c|}{ Alcohol consumption } & \multicolumn{2}{|c|}{ Depression } \\
\hline & & $M$ & $S D$ & $M$ & $S D$ & $M$ & $S D$ \\
\hline \multirow{2}{*}{ Robbery } & Male & 17.9 & 4.9 & 7.7 & 3.8 & 23.1 & 9.8 \\
\hline & Female & 18.7 & 3.5 & 6.0 & 3.4 & 30.2 & 4.2 \\
\hline \multirow{2}{*}{ Kidnapping } & Male & 17.4 & 1.5 & 8.1 & 3.3 & 24.5 & 3.7 \\
\hline & Female & 19.2 & 3.1 & 6.4 & 3.7 & 28.0 & 4.8 \\
\hline \multirow{2}{*}{ Rape } & Male & 17.0 & 3.6 & 7.7 & 4.1 & 27.0 & 4.6 \\
\hline & Female & 19.7 & 4.7 & 7.0 & 5.2 & 23.3 & 2.1 \\
\hline \multirow{2}{*}{ Crimes vs health } & Male & 17.7 & 2.4 & 8.5 & 3.7 & 26.2 & 3.8 \\
\hline & Female & 17.6 & 2.2 & 5.9 & 2.9 & 29.6 & 4.3 \\
\hline \multirow{2}{*}{ Homicide } & Male & 16.9 & 3.7 & 8.0 & 4.1 & 25.9 & 6.3 \\
\hline & Female & 21.9 & 5.5 & 7.1 & 4.4 & 29.0 & 4.7 \\
\hline \multirow{2}{*}{ Others } & Male & 16.9 & 1.9 & 8.3 & 4.3 & 25.6 & 5.6 \\
\hline & Female & 19.2 & 4.6 & 5.8 & 2.3 & 29.1 & 4.2 \\
\hline Sex and type of crime & $F=$ & \multicolumn{2}{|c|}{$3.49^{* *}$} & \multicolumn{2}{|c|}{.41} & \multicolumn{2}{|c|}{1.65} \\
\hline
\end{tabular}

Note: ${ }^{* *} p<.01$.

\section{Discussion}

The purpose of this study was to examine the differences in domestic violence, alcohol consumption and depressive symptoms on the type of crime committed between men and women inmates of Social Rehabilitation Centre (CERESO) of the State of Morelos, this with the purpose of having evidence to develop strategies for prevention of criminal conduct, and to build health care programs for the prison population in these centers.

The proportion of prisoners with some grade of upper education was lower than that reported for the general population which was 14.5\% in 2005 (INEGI, 2005). The marginalization and violence in childhood home had a negative association with habitual drug and alcohol consumption and family violence that could be related to alcohol and drug use in the childhood locality.

In general, the results showed significant differences by sex but not by type of crime committed, specifically domestic violence, which found that women had higher scores than men. According to Rodriguez, Romero, Durand, Colmenares and Saldivar (2006), women who commit criminal acts are those that most often reported having experienced some form of violence at home, which, according to these authors could be an enabling environment that favors getting involved in this kind of behavior.

Related to alcohol consumption prior to admission to the prison, although differences were not statistically significant, the findings show that men had higher scores than women. Furthermore, the analysis by type of crime committed, found that a higher number of subjects with severe consumption were entered on charges of health damages and homicides, which agrees with the proposal by other authors (Grann \& Fazel, 2004; Norstrom, 1998; Von Hofer, 2003) whom suggest that alcohol consumption is associated with the presence of criminal acts such as murder and assault.

The results of this study showed that women had more depressive symptoms than men; however, these differences were not significant. According to Romero and Aguilera (2002), the fact of being detained in one of these rehabilitation centers could be related to depressive symptoms due to the various constraints (social, familiar and economic), specifically in women, Galván, Romero, Rodriguez, Durand, Colmenares and Saldivar (2006) found that the low frequency of visits and the separation from their children are issues that are related to the presence of depressive episodes.

As shown in other studies of mexican delinquency (NevarezSida, 2012), criminal activity related to substance abuse importantly increases the possibility that the prisoner consumed 
drugs and alcohol prior to detention. Once in prison, the relation between the type of crime and substance abuse is not as relevant. The negative impact of prison-since alcohol and drug consumption in prison is generalized-the abuse is determined by availability of the substances.

As mentioned previously, the information obtained by this study, is a relevant tool as well as an important element of analysis for the development of intervention strategies, preventive policies and developing intervention programmes in the crime field (by prison, by the government by psychologists, etc.).

Considering the fact that most of these women and men had a childhood and probably a lifetime living near of at least one mental disorder, -including substance misuse disorders and personality disorders-, indicates a need for improving services, particularly within the prisons. Planning and improving psychological services for sentenced prisoners may be an opportunity to treat disorders related to substance use, violence and depression and to demonstrate the importance of community detection and monitoring programmes aiming prevention of delinquency.

\section{REFERENCES}

Chiles, J. A., Cleve, E., Jemelka, R. P., \& Trupin, E. W. (1990). Substance abuse and psychiatric disorders in prision inmates. Hospital and Community Psychiatry, 41, 1132-1134.

Cicchetti, D. (2004). An odyssey of discovery: Lessons learned through three decades of research on child maltreatment. American Psychologist, 59, 731-741. doi:10.1037/0003-066X.59.8.731 doi:10.1007/s00787-002-0275-1

Fagan, A. A., Van Horn, V. L., Hawkins, J. D., \& Arthur, M. W. (2007). Gender similarities and differences in the association between risk and protective factors and self-reported serious delinquency. Prevention Science, 8, 115-124. doi:10.1007/s11121-006-0062-1

Fazel, S., \& Danesh, J. (2002). Serious mental disorder in 23,000 prisoners: A systematic review or 62 surveys. Lancet, 359, 545-550. doi:10.1016/S0140-6736(02)07740-1

Fresan, A., Tejero, J., Apiquian, R., Loyzaga, C., García-Anaya, M., \& Nicolini, H. (2002). Aspectos penales y características clínicas de la criminalidad en la esquizofrenia. Salud Mental, 25, 72-78.

Frías, A. M., Sotomayor, P. M., Varela, C. C. B., Zaragoza, O. F., Banda, C. A. L., \& García, S. A. (2000). Predictores de la delincuencia juvenil. La Psicología Social en México, 8, 486-492.

Galván, J., Romero, M., Rodríguez, E. M., Durand, A., Colmenares, E., \& Saldívar, G. (2006). La importancia del apoyo social para el bienestar físico y mental de las mujeres reclusas. Salud Mental, 29, 68-74.

Gorman-Smith, D., \& Loeber, R. (2005). Are developmental pathways in disruptive behaviors the same for girls and boys? Journal of Child and Family Studies, 14, 15-27. doi:10.1007/s10826-005-1109-9

Grann, M., \& Fazel, S. (2004). Substance misuse and violent crime: Swedish population study. British Medical Journal, 328, 1233-1234. doi:10.1136/bmj.328.7450.1233

Hart, J. L., O’Toole, S. K., Price-Sharps, J. L. \& Shaffer, T. W. (2007). The risk and protective factors of violent juvenile offending: An examination of gender differences. Youth Violence and Juvenile Justice, 5, 367-384. doi:10.1177/1541204006297367

Heise, L. L, Pitanguy, H., \& Germain, A. (1994). Violence against women: The hidden health burden. Washington DC: World Bank.

Hernández, Z. E., \& Márquez, M. L. (2000). El perfil del homicida y delincuente sexual: El punto de vista de la salud mental. Psicología de la Salud, 10, 103-114.

Huizinga, D., \& Jakob-Chien. C. (1998). The contemporaneous cooccurrence of serious and violent juvenile offending and other problem behaviors. In R. Loeber, \& D. Farrington (Eds.), Serious \& violent juvenile offenders: Risk factors and successful interventions (pp.
47-67). Thousand Oaks, CA: Sage Publications

Instituto Ciudadano de Estudios sobre la Inseguridad (2009). Sexta Encuesta Nacional sobre Inseguridad. URL (last checked November 2012).

http://www.inegi.org.mx/est/contenidos/Proyectos/encuestas/hogares /especiales/ensi/ensi2009/default.aspx

Instituto Nacional de Estadística Geografía e Informática INEGI: II Conteo de Población y Vivienda 2005. México City: Instituto Nacional de Estadística Geografía e Informática, 2008 [Spanish].

Ireland, T. O., Smith, C. A., \& Thornberry, T. P. (2002). Developmental issues in the impact of child maltreatment on later delinquency and drug use. Criminology, 40, 359-399. doi:10.1111/j.1745-9125.2002.tb00960.x

Mariño, M. C., Medina-Mora, M. E., Chaparro, J. J., \& GonzálezForteza, C. (1993). Confiabilidad y estructura factorial del CES-D en adolescentes mexicanos. Revista Mexicana de Psicología, 10, 141145.

Martínez-Lanz, P., Betancourt, O. D., Rendón, B. L., \& Burns, T. A. (2012). Factores de riesgo asociados a la delincuencia masculina en México: Un estudio a reclusos de un centro de readptación social varonil. Revista Criminalidad, 54, 359-377.

Martínez-Lanz, P., Lobo, M. G., \& Vecchi, M. G. (2012). Violencia y depresión como factores de riesgo en la delincuencia varonil. In R. Díaz-Loving, A. S. Rivera, \& L. I. Reyes, (Eds.), La psicología social en México XIV (pp. 99-104). México City: Asociación Mexicana de Psicología Social

Nebbitt, V. E., \& Lombe, M. (2008). Assessing the moderating effects of depressive symptoms on antisocial behavior among urban youth in public housing. Child and Adolescent Social Work Journal, 25, 409-424. doi:10.1007/s10560-008-0134-0

Norstrom, T. (1998). Effects on criminal violence of different beverage types and private and public drinking. Addiction, 93, 689-699. doi:10.1046/j.1360-0443.1998.9356895.x

Novak, A., Burgess, E., \& Clark, M. (2003). Anxiety sensitivity, selfrepoted motives for alcohol and nicotine use, and level of consumption. Journal Anxiety Disorders, 17, 165-180. doi:10.1016/S0887-6185(02)00175-5

Pérez, A. L. T., \& Pinzon, I. X. (2009). Factores psicosociales asociados a la conducta delictiva de los internos condenados por homicidio recluidos en la cárcel de máxima seguridad de Combita (Boyacá). Revista Virtual de la Universidad Católica del Norte, 26.

Pliszka, S., Sherman, J., Barrow, M., \& Irick, S. (2000). Affective disorder in juvenile offenders: A preliminary study. American Journal of Psychiatry, 157, 130-132.

Radloff, L. S. (1977). The CES-D Scale: A self-report depression scale for research in the general population. Applied Psychological Measurement, 1, 385-401. doi:10.1177/014662167700100306

Rodríguez, E. M., Romero, M., Durand, A., Colmenares, E., \& Saldívar, G. (2006). Experiencias de violencia física ejercida por la pareja en las mujeres en reclusión. Salud Mental, 29, 59-67.

Romero, M. (2003). Por qué delinquen las mujeres? Parte II. Vertientes analíticas desde una perspectiva de género. Salud Mental, 26, 32-41.

Romero, M., \& Aguilera, R. M. (2002). Por qué delinquen las mujeres? Parte I. Perspectivas teóricas tradicionales. Salud Mental, 26, 32-41.

Sabol, W. J., Coulton, C. J., \& Korbin, J. E. (2004). Building community capactiy for violence prevention. Journal of Interpersonal Violence, 19, 322-340. doi:10.1177/0886260503261155

Sanders-Phillips, K. (2001). The power of race/ethnicity. Culture and science in understanding drug abuse, bridging science and culture to improve drug abuse research in minority communities. Philadelphia, PA: National Institute on Drug Abuse,

Stewart, S., Karp, J., Phil, O., \& Peterson, R. A. (1997). Anxiety sensitivity and self-reported reasons for drug use. Journal of Substance Abuse, 9, 223-240. doi:10.1016/S0899-3289(97)90018-3

Tapia, C. R., Cravioto, P., De la Rosa, B., Kuri, P., \& Gómez, H. (1995). Encuesta Nacional de Adicciones 1993. Salud Pública de México, 37, 83-87.

Thornberry, T. P., Ireland, T. O., \& Smith, C. A. (2001). The importance of timing: The varying impact of childhood and adolescent maltreatment on multiple problem outcomes. Development and Psychopathology, 13, 957-979. 
Vermeiren, R., Deboutte, D., Ruchkin, V., \& Schwab-Stone, M. (2002). Antisocial behavior and mental health: Findings from three communities. European Child Adolescent Psychology, 11, 168-175.

Vicens, E., Tort, V., Dueñas, R. M., Muro, A., Pérez-Arnau, F., Arroyo, J. M., Acín, E., Vicente, A., Guerrero, R., Lluch, J., Planella, R., \& Sarda, P. (2012). The prevalence of mental disorders in Spanish prisoners. Criminal Behavior and Mental Health, 21, 321-332. doi:10.1002/cbm.815
Vladimirsky, G., Sánchez, M. O. P., \& Marín, C. A. E. (2003). Consecuencias del maltrato infantil en la autoestima y desempeño escolar. Tesina de Licenciatura, México City: Universidad Anáhuac. Von Hofer, H. (2003). Crime and punishment in Sweden: Historial criminal justice statistics 1750-2000. Journal of Scandinavian Studies in Criminology and Crime Prevention, 4, 162-179. doi:10.1080/14043850310021576 